Jap. J. Leprosy 58, 235-240 (1989)

\title{
The Experimental Inoculation with Mycobacterium leprae in Autoimmune Mice : Results of MRL/lpr Mice Inocu- lated into the Right Hind Foot (continued)
}

\author{
Yasuko YOGI ${ }^{(1)}$ KazUnari NAKAMURA ${ }^{(1)}$ and Akira SUZUKI ${ }^{(2)}$ \\ (1: National Institute for Leprosy Research, Tokyo JAPAN 2 : Kitasato University, \\ School of Hygienic Sciences, Sagamihara, JAPAN)
}

(Received for publication: May 26,1989)

Key wards : Mycobacterium leprae, autoimmune mouse, $l p r$ gene, MRL/lpr, NOD.

Susceptibility to Mycobacterium leprae of nude mice has been studied on various strains, and the importance of genetic backgrounds in relation to the development of lepromatous lesions has been pointed out and reported especially NFS/N and N:NIH(s) nude mice were high susceptibility to $M$.leprae. Additionally, NOD hybrid nude mice developed by the transfer the Crj:CD. 1 (ICR) nude gene were high susceptibility to $M$.leprae while that of their original NOD(Nonobese diabetic) mice which were developed experimental animal for the study of insulin-dependent diabetes mellitus (IDDM) were confined to multiplication of $M$.leprae. ${ }^{(1,2)}$

The autoimmune MRL/lpr mouse bearing $l p r$ gene was established by Murphy and Roths, Jackson laboratory, U.S.A. has been a very useful model for study of spontaneous systemic lupus erythematosus(SLE). Many immunological abnormalities of $\mathrm{T}$ cells have been found as compared with $\mathrm{NZB},(\mathrm{NZB} \times \mathrm{NZW}) \mathrm{F} 1$ and $\mathrm{BXSB}$ mice. MRL/lpr mouse develop massive generalized lymph node enlargement, more than $90 \%$ of the cells in the enlarged lymph nodes is positive for Thy- $1^{+}$antigen. Older MRL/lpr mouse has a necrotizing exudative polyarteritis. Also, MRL/lpr mouse was confirmed rheumatoid factors of both the IgM and IgG, this is an excellent experimental model rheumatoid arthritis (RA) as well as for human SLE. ${ }^{(3)}$

In the present study, we have undertaken a comparison of susceptibility to $M$.leprae of autoimmune MRL/lpr mice (model for SLE and RA) with autoimmune NOD mice (model for IDDM), descriptions were made as high susceptibility to $M$. leprae of MRL/lpr mice as well as previously reported by using $\mathrm{F}_{2}(l p r / l p r \cdot+/+)$ mice of $\mathrm{MRL} / \mathrm{lpr} \times \mathrm{Crj}: \mathrm{CD}-1(\mathrm{ICR})-n u\left(\mathrm{M}_{1}\right) .^{(4)}$

\section{Materials and Methods}

MRL/lpr and NOD mice were obtained from CLEA, Tokyo. Crj:CD-1(ICR) mice were obtained from Charles River, Atsugi, Japan. Thirty MRL/lpr mice and 20 NOD mice of 12-16 weeks old, and $20 \mathrm{Crj}: \mathrm{CD}$-1(ICR) mice of 6 weeks old were used. The inoculum size of $M$. leprae derived from the foot passage of nude mice was $5.8 \times 10^{6}$ bacilli. The inoculation was made at the right dorsal site of the hind foot. The MRL/lpr mice were maintained in a vinyl isolator under specific pathogen free conditions, and were provided with sterilized autoclavable commercial diet (CE-2, CLEA, JAPAN) and tap water ad libitum. NOD and Crj:CD-1(ICR) mice were housed in a conventional animal room. 
For identification, the harvested acid fast bacilli(AFB) from the MRL/lpr mice 240 days after inoculation, were reinoculated into the right hind foot of Crj:CD-1(ICR) mice in order to confirm the growth pattern (persistent infection) in the mice. The AFB obtained were cultured on a $1 \%$ Ogawa's medium and a modified Nemoto's egg yolk medium at $33^{\circ} \mathrm{C}$ and $37^{\circ} \mathrm{C}$ for 3 months. Acid-fast stainig of the smears of AFB was carried out by pyridine extraction method as modified by us. ${ }^{(5)}$ Besides, the tissues obtained from infected MRL/lpr mice were fixed in buffered formaldehyde solution, and stained with Fite-Faraco's and Haematoxylin-Eosin.

\section{Results}

In this experiment, we used MRL/ $l p r$ mice of 20 male and 10 female with already developed massive generalized lymph node enlargement as shown in Fig. 1. Used NOD and Crj:CD-1 (ICR) mice were male of 10 and female of 10 . The multiplication at 105 days and 240 days of $M$. leprae inoculated into the right hind foot of the MRL/lpr, NOD and Crj:CD-1 (ICR) mice were shown in Table 1. In the column of 240 days after inoculation, the bacillary some male MRL/lpr mice were increased to $10^{8}-10^{9}$ bacilli per foot, whereas NOD mice was approximately $10^{4}$ bacilli per foot showing decrease in number of $M$.leprae. Histopathological section of the infected foot of $\mathrm{MRL} / \mathrm{lpr}$ mice the 240 days after inoculation indicated the presence of a number of bacilli and globi around blood vessels in subcutaneous tissue or muscular layer on Fite-Faraco's stain as shown in Fig. 2 or Fig. 3. Also, their mice were observed to have systemic degenerative vascular disease. As shown in Fig. 4, the coronary granulomatous arteritis was observed in the inoculated foot.

The AFB isolated from the MRL/lpr mice were distinguished $M$.leprae from other mycobacteria. Results of reinoculation in normal mice were no swelling nor any other macroscopic lesions and the multiplication was confined to the site of inoculation. The cultivation on $1 \%$ Ogawa's medium and modified Nemoto's egg yolk medium at $33^{\circ} \mathrm{C}$ and $37^{\circ} \mathrm{C}$ for 3 months was all negative.

Acid-fast stainability of this bacilli was lost by pyridine extraction test. Therefore, the AFB grown in experimental mice were identified as $M$.leprae from these findings.

Table $1:$ Number of $M$.leprae in right hind footpads of $\mathrm{MRL} / l p r$, NOD and Crj:CD-1(ICR) mice

\begin{tabular}{|c|c|c|c|c|}
\hline \multirow{2}{*}{ Background } & \multicolumn{2}{|r|}{ Days after } & \multicolumn{2}{|c|}{ inoculation } \\
\hline & \multicolumn{2}{|c|}{105} & \multicolumn{2}{|c|}{240} \\
\hline \multirow{5}{*}{$\mathrm{MRL} / l p r$} & $7.3 \times 10^{5}$ & $1.4 \times 10^{8}$ & $8.8 \times 10^{8}$ & $2.3 \times 10^{9}$ \\
\hline & $2.9 \times 10^{7}$ & $2.8 \times 10^{8}$ & $5.0 \times 10^{8}$ & $8.1 \times 10^{8}$ \\
\hline & $5.6 \times 10^{6}$ & $8.0 \times 10^{7}$ & $7.2 \times 10^{7}$ & $9.0 \times 10^{8}$ \\
\hline & $9.2 \times 10^{6}$ & $3.1 \times 10^{6}$ & $3.5 \times 10^{7}$ & $7.8 \times 10^{6}$ \\
\hline & $5.0 \times 10^{5}$ & & $4.5 \times 10^{7}$ & \\
\hline \multirow{3}{*}{ NOD } & $5.4 \times 10^{5}$ & $1.7 \times 10^{5}$ & $3.1 \times 10^{4}$ & $2.5 \times 10^{5}$ \\
\hline & $3.8 \times 10^{4}$ & $9.1 \times 10^{4}$ & $5.3 \times 10^{4}$ & $1.8 \times 10^{4}$ \\
\hline & $7.5 \times 10^{4}$ & & $8.9 \times 10^{4}$ & \\
\hline \multirow{3}{*}{ Crj:CD-1 (ICR) } & $6.2 \times 10^{5}$ & $2.7 \times 10^{6}$ & $4.5 \times 10^{5}$ & $3.7 \times 10^{6}$ \\
\hline & $7.8 \times 10^{5}$ & $4.5 \times 10^{5}$ & $1.7 \times 10^{5}$ & $6.5 \times 10^{5}$ \\
\hline & $2.3 \times 10^{5}$ & $8.9 \times 10^{4}$ & $6.8 \times 10^{4}$ & \\
\hline
\end{tabular}

Inoculum size $\cdots 5.8 \times 10^{6}$ bacilli $/$ hind footpad 


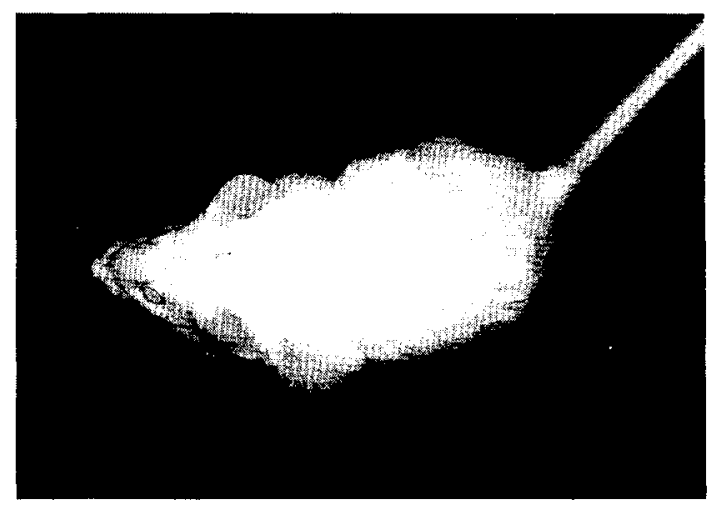

Fig. 1 A MRL/lpr mouse showing the enlargement of axillary lymph node. On 110 days after birth.

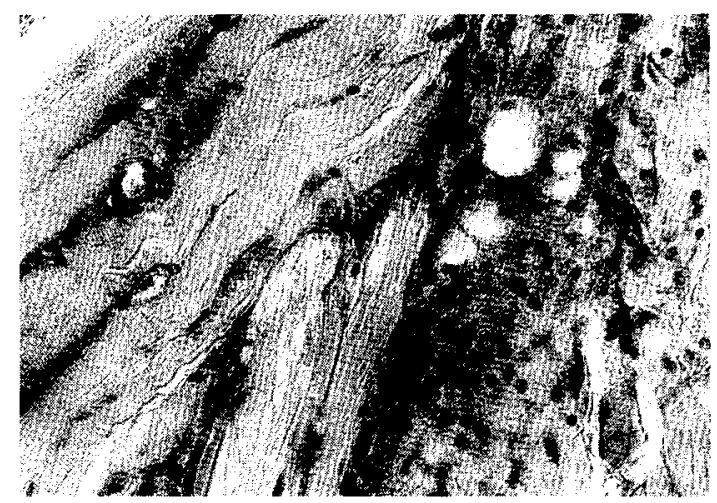

Fig. 3 ditto. A large number of bacilli are seen in muscular layer and subcutaneous tissue. Fite-Faraco's stain.

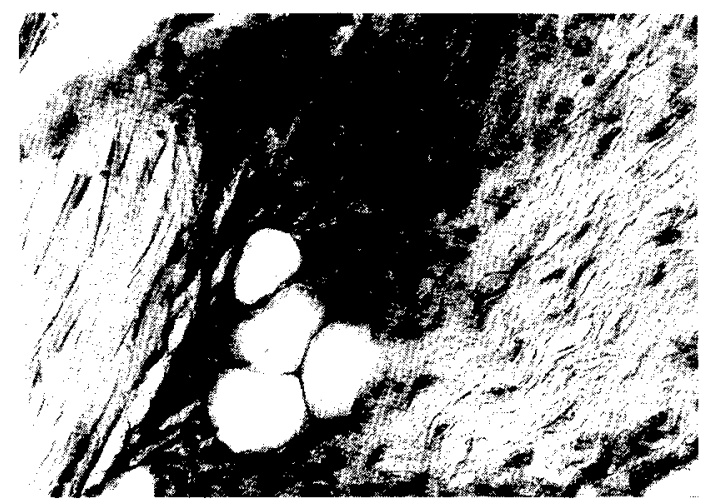

Fig. 2 A large number of bacilli are observed around blood vessels in subcutaneous lesion in a MRL/lpr mouse. On 240 days after inoculation with $M$.leprae. Fite-Faraco's stain.

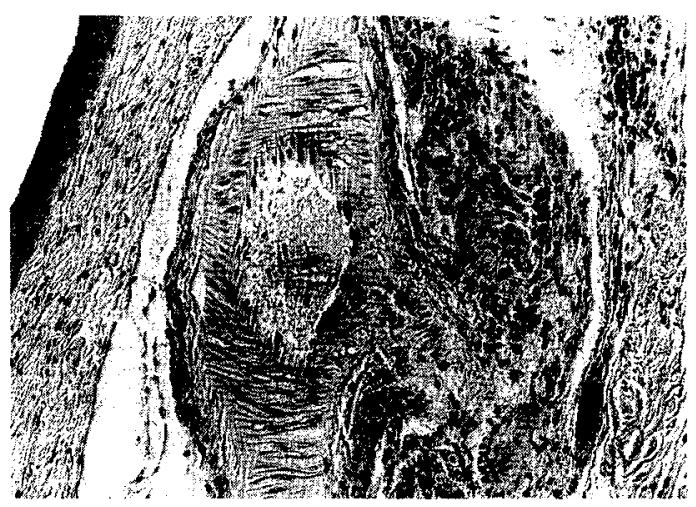

Fig. 4 ditto. Subcutaneous lesion of foot accompanied with arteritis in MRL/lpr mouse. H\&E stain. 


\section{Discussion}

The MRL/lpr, autoimmune mice bearing $l p r$ gene has been a very useful model to study the spontaneous systemic lupus erythematosus(SLE) and rheumatoid arthritis(RA)(3). The NOD mouse is a model of human insulin-dependent diabetes mellitus(IDDM), the diabetic processes appear to reflect an autoimmune responce to the $\beta$ cells with in the islets of the pancreas. $T$ lymphocytes play an important role in the initiation of insulitis. In the pancreas of NOD mice, a predominant infiltration by activated $T$ lymphocytes, including helper/inducer and cytotoxic/ suppressor $\mathrm{T}$ cell, was observed in insulitis. Natural killer cells were also detected in the lesions. As for splenic $T$ cell subsets, cytotoxic suppressor $T$ cells were increased in NOD mice ${ }^{(6,7)}$. On the other hand, autoimmune MRL/lpr mice is also T cell dependent. However these T cells have the following characteristics. Morse et al. ${ }^{\left({ }^{8}\right)}$ or Wofsy et al ${ }^{\left({ }^{(9)}\right.}$ reported that the proliferating cells in enlarged abnormal lympho nodes express Thy- $1^{+}, \mathrm{L} 3 \mathrm{~T}^{-}$and Lyt-2- (double negative of Th and Ts) and B220+, and prud'homme et al. ${ }^{(10)}$ suggested an association of L-BCDF (B cell differentiation factor) which were produced spontaneously from the proliferating unusual cells with autoimmunity. However, recently, Santoro et al. ${ }^{(1)}$ or Jabs and prendergast ${ }^{(12)}$ demonstrated that the presence of functional abnormalities in splenic or enlarged nodes $\mathrm{L} 3 \mathrm{~T}^{+}$cells from $\mathrm{MRL} / \mathrm{pr}$ mice. Moreover, Santoro et al. ${ }^{(13)}$ or Asano et al. ${ }^{(14)}$ have suggested an important role for the $T$ cell subset which were failed to produce interleukin 2(IL-2), expressing B220 and L3T4 in the pathogenesis of disease in $l p r$-bearing mice. Furthermore, interleukin 3(IL-3), interleukin 6(IL6) production in MRL/lpr mice were markedly increased ${ }^{(15,16)}$. Functional abnormalities of macrophages in MRL/lpr mice have shown an increased frequency of $\mathrm{Ia}^{+}$resident $^{(17)}$, also Nose et al. demonstrated the presence of MRL/lpr-MAF (macrophage activating factor derived from $\mathrm{MRL} /(p r)$ which were produced spontaneously ${ }^{(18)}$. Okuyama et al ${ }^{(19)}$ reported that the ability to induce DTH against exogeneous antigenic stimulation of MRL/lpr mice decreased with age. In view of the findings stated above, it is interesting to consider that the MRL/lpr mice would support the multiplication of $M$. leprae, while that of NOD mice would not support the growth of $M$.leprae. Also, it was confirmed the association with a genetic factor, for example, a factor the cause vascular lesions may be accessary for the development of marked lesions in addition to accelete $l p r$ gene with autoimmune-prone background gene of MRL/lpr mice.

\section{Summary}

Using MRL/lpr, NOD and Crj:CD-1 (ICR) mice, inoculations of $M$. leprae were made into the right hind foot at a dose of $5.8 \times 10^{6}$ bacilli per foot in order to study the influence of the immunobiological characteristics of their mice on the growth of $M$.leprae. To summarize of the results, MRL/lpr mice showed the high susceptibility to $M$.leprae, while that of NOD mice were poor. In conclusion, the immunobiological characteristics of MRL/lpr, autoimmune mice bearing $l p r$ gene had effect on the multiplication of $M$. leprae, this mouse is a suitable multibacillary model for the study of leprosy.

\section{Acknowledgements}

This study was supported in part by U.S.-Japan Cooperative Medical Science Program, and the Sasakawa Memorial Health Foundation, and the results obtained were reported at the 62nd General 
meeting of Japanese Leprosy Association in Furukawa,1989. Also, we will be report at the 24th U. S.-Japan Joint Conference on Leprosy Research in San Diego, California, 1989.

\section{References}

1) Nakamura,K. and Yogi,Y.: The nude mouse as an experimental lepromatous leprosy model (continued): The NFS/N nude mouse as a new model using the intra-upper lip inoculation method. Jap. J. Lepr., 57, 129-136(1988)

2) Yogi,Y. and Nakamura, K.: Mycobacterium leprae-susceptibility of NOD hybrid nude mice. Jap. J. Lepr., 57, 117-121(1988)

3) Theofilopoulos, A. N. and Dixon, F.: Murine models of systemic lupus erythematosus. Adv. Immunol, , 37, 269-390(1985)

4) Yogi, Y . and Nakamura, K.: The experimental inoculation with Mycobacterium leprae in hybrid mice with autoimmune and nude mice (continued): Susceptibility to $M$. leprae of MRL/lpr (M1) and NOD (M2) hybrid nude mice. Ann. Rep. Natl. Inst. Lep. Res. (Tokyo) 33, 28-32 (1987) (in Japanese)

5 ) Nakamura, K. et al.: Concerning the decrease of acid-fastness by solvent treatment of pyridine of in vitro M. lepraemurium. Ann. Rep. Natl. Inst. Lep. Res. (Tokyo), 18, 17(1972) (in Japanese)

6) Makino, S. et al.: Breeding of a non-obese diabetic strain of mouse. Exp. Anim., 29, 1-13(1980)

7 ) Miyazaki, A. et al.: Predominance of $\mathrm{T}$ lymphocytes in pancreatic islets and spleen of pre-diabetic non-obese diabetic(NOD) mice : A longitudinal study. Clin. Exp. Immunol., 60, 622-630(1985)

8 ) Morse, H. C. et al.: Abnormalities induced by the mutant gene lpr: Expansion of a unique lymphocyte subset. J. Immunol. 129, 2612-2615(1982)

9 ) Wofsy, D. et al.: The proliferating cells in autoimmune MRL/lpr mice lack L3T4, an antigen on "helper" $\mathrm{T}$ cells that is involved in the response to class II major histocompatibility antigens. J. Immunol., 132, 2686-2689(1984)

10) Prud'homme,G.J. et al.: Identification of a B cell differentiation factor $(\mathrm{s})$ spontaneously produced by proliferating $\mathrm{T}$ cells in murine lupus strains of the $\mathrm{lpr} / \mathrm{lpr}$ genotype. J. Exp. Med., 157, 730742 (1983)

11) Santoro, T.J. et al.: The role of ${\mathrm{L} 3 \mathrm{~T} 4^{+}}^{+}$cells in the pathogenesis of lupus in $l p r$-bearig mice.

1. Defects in the production of interleukins 2 and 3. Eur. J. Immunol., 17, 1131-1138(1987)

12) Jabs,D.A. and Prendergast, R. A. : Reactive lymphocytes in lacrimal gland and vasculitic renal lesions of autoimmune MRL/lpr mice express L3T4. J. Exp. Med., 166, 1198-1203(1987)

13) Santoro, T. J. et al.: The contribution of L3T $4^{+} \mathrm{T}$ cells to lymphoproliferation and autoantibody production in MRL-lpr/lpr mice. J. Exp. Med., 167, 1713-1718(1988)

14) Asano, $T$. et al. : A new $\mathrm{T}$ cell subset expressing B220 and CD4 in 1pr mice : defects in the response to mitogens and in the production of IL-2. Clin. Exp. Immumol., 74, 36-40(1988)

15) Palacious, R. : Spontaneous production of interleukin 3 by $T$ lymphocytes from autoimmune-MRL/ lpr mice. Eur. J. Immunol., 14, 599-605(1984)

16) Tang, Bo et al. : abnormality production of interleukin 6 in MRL/lpr mice. Proc. Jpn. Soc. Immunol., 18, 400(1988) (in Japanese)

17) Kelley, V. E. and Roths, J. B. : Increase in macrophage Ia expression in autoimmune mice. Role of the lpr gene. J. Immunol. 129, 923-925(1982)

18) Nose, M. et al. : Macrophage functions and their regulation in MRL/l lupus mice. In new horizons in animal models for autoimmune disease. Academic press, Tokyo, 219-231(1987).

19) Okuyama, $\mathrm{H}$. et al. : Analysis of defective delayed-type hypersensitivity in autoimmune mice bearing 
lpr gene. Clin. Exp. Immunol., 63, 87-94(1986)

\section{自己免疫疾患モデルマウスへのらい菌接種：MRL/lpr マウスの 右後肢足内における成績について（続報）}

與儀ヤス子(1) 中村一成 ${ }^{1)}$ 鈴木 昭2)

(1：国立多摩研究所 2 : 北里大学衛生学部)

キーワード : らい菌, 自己兔疫マウス, $l p r$ 遺伝子, MRL/lpr, NOD

$\mathrm{MRL} / \mathrm{lp} r$ マウスは，ヒトの全身性エリテマトー デス，慢性関節りウマチのモデルマウスとして広く 利用されている。このマウスは，1個の常染色体性 劣性の $l p r$ 遺伝子とその遺伝的背景の修飾をうけて, $\mathrm{T}$ 細胞の異常增殖による全身性リンハ節腫脹を呈し, 免疫複合体性腎炎，血管炎，慢性関節炎等を自然発 症する。同じく T細胞依存性に藏器特異的自己免疫
疾患（やせ型インシュリン依存性糖尿病）を自然発 症するNODマウスとともにらら菌接種を行った 結果, NODマウスがらい菌の增殖に抑制的だった のに対して，MRL/lpr マウスは高いらい菌感受性 を示した。 